\title{
LEGAL OPINI ATAS PUTUSAN PENGADILAN TINDAK PIDANA KORUPSI PADA PENGADILAN NEGERI MEDAN NOMOR 13/PID.SUS-TPK/2018/PN MEDAN, TANGGAL 19 APRIL
}

\author{
Maidin Gultom \\ Fakultas Hukum Universitas Katolik Santo Thomas, Medan, Indonesia \\ Email : gultommaidin@gmail.com
}

\begin{abstract}
ABSTRAK
Pasal 12 a UU PTPK hanya berlaku untuk Pegawai Negara dan Penyelenggara Negara. Pasal 12 a UU PTPK pada dasarnya mengatur tentang perbuatan pegawai negeri atau penyelenggara negara yang bertentangan dengan tugas atau kewajibannya. Terpidana Sujendi Tarsono alias Ayen bukan merupakan Pegawai Negeri atau Penyelenggara Negara. Yang bersangkutan adalah sebagai wiraswasta sebagai Direktur PT Ada Mobil/Pemilik Ada Jadi Mobil. Berkaitan dengan uraian di atas, kemungkinan yang terjadi adalah terjadinya error in persona dan Error in Objecto, artinya salah orang dan salah objek yang diputuskan kepada terpidana Sujendi alias Ayen. Menurut hemat saya, terdakwa SUJENDI TARSONO alias AYEN dapat dikategorikan dalam Turut Serta dalam dalam hal ini Menyuruh Melakukan (Middelijk daders). Menyuruh melakukan adalah seseorang yang berkehendak untuk melakukan sesuatu tindak pidana, akan tetapi tidak melakukannya sendiri, melainkan menyuruh orang lain untuk melakukannya. Orang yang menyuruh itu menggunakan orang lain (yaitu orang yang disuruh) untuk mewujudkan niatnya. Syarat utama (ciri khas) dari menyuruh melakukan adalah bahwa seorang yang disuruh itu haruslah orang yang tidak dapat dipertanggungjawabkan secara hukum (menurut Hukum Pidana). Alasannya adalah sebagai berikut: a. Karena adanya pengecualian pidana. b. Karena salah satu unsur tindak pidana itu tidak dipenuhi, misalnya unsur kesalahan (kesengajaan), yang berkaitan dengan niat (sebagai unsur subjektif) dalam terjadinya tindak pidana. Yang menyuruh melakukan yang bersalah (mensrea) sedangkan yang melakukan tidak mempunyai kesalahan. Pertanggungjawaban dari orang yang menyuruh melakukan dibatasi hanya sampai pada perbuatan yang dilakukan oleh pembuat materil (orang yang disuruh).
\end{abstract}

Kata Kunci : Legal Opini, Putusan Pengadilan, Tindak Pidana, Korupsi

\begin{abstract}
Article 12 a PTPK Law only applies to State Employees and State Administrators. Article 12 a PTPK Law basically regulates the actions of civil servants or state administrators that are contrary to their duties or obligations. The convict Sujendi Tarsono alias Ayen is not a Civil Servant or a State Administrator. The person concerned is as an entrepreneur as Director of PT Ada Mobil / Owner Ada Jadi Mobil. In connection with the description above, the possibility that occurs is the occurrence of errors in persona and Error in Objecto, meaning that the wrong person and the wrong object that was decided to convict Sujendi alias Ayen. In my opinion, Legal Opini Atas Putusan Pengadilan Tindak Pidana Korupsi Pada Pengadilan Negeri Medan Nomor 13/Pid.Sus-TPK/2018/PN Medan, Tanggal 19 April

Oleh : Maidin Gultom


the defendant SUJENDI TARSONO alias AYEN can be categorized as Also Participating in this case Telling Doing (Middelijk daders). Forcing to do is someone who wishes to do something criminal, but does not do it himself, but rather tells others to do it. The person who ordered it uses someone else (ie the person who was told) to realize his intention. The main requirement (characteristic) of ordering to do is that the person who is told to be must be a person who cannot be accounted for legally (according to Criminal Law). The reasons are as follows: a. Because of criminal exemptions. b. Because one element of the crime was not fulfilled, for example the element of error (intentional), which is related to the intention (as a subjective element) in the occurrence of the crime. Those who do what is wrong (menrea) while those who do have no mistakes. The liability of the person who ordered it to do is limited to the act carried out by the material maker (the person ordered).

Keywords: Legal Opinion, Court Decision, Criminal Acts, Corruption

\section{A. PENDAHULUAN}

\section{Pasal 12 UUPTPK menentukan:}

Dipidana dengan pidana penjara seumur hidup atau paling singkat 4 (empat) tahun dan paling lama 20 (dua puluh) tahun dan pidana denda paling sedikit Rp. 200.000.000,- (dua ratus juta rupiah) dan paling banyak Rp. 1.000.000.000,- (satu milyar rupiah).

a. Pegawai Negeri atau penyelenggara negara yang menerima hadiah atau janji, padahal diketahuinya atau patut diduga hahwa hadiah atau janji tersebut diberikan untuk menggerakkan agar melakukan atau tidak melakukan sesuatu dalam jabatannya, yang berhubungan dengan kewajibannya.

b. Pegawai negeri atau penyelenggara negara yang menerima hadiah, padahal diketahui atau patut diduga bahwa hadiah tersebut diberikan sebagai akibat atau disebabkan karena telah melakukan atau tidak melakukan sesuatu dalam jabatannya yang bertentangan dengan kewajibannya.

c. Hakim yang menerima hadiah atau janji, padahal diketahui atau patut diketahui diduga bahwa hadiah atau janji tersebut diberikan untuk mempengaruhi putusan perkara yang diserahkan kepadanya untuk diadili.

d. Seseorang yang menurut ketentuan peraturan perundang-undangan ditentukan menjadi advokat untuk menghadiri sidang pengadilan. Menerima janji atau hadiah, padahal diketahui atau patut diduga bahwa, hadiah atau janji tersebut untuk mempengaruhi nasihat atau pendapat 
yang akan diberikan, berhubung dengan perkara yang diserahkan kepada pengadilan untuk diadili.

e. Pegawai negeri atau penyelenggara negara yang dengan maksud menguntungkan diri sendiri atau orang lain secara melawan hukum, atau dengan menyalahgunakan kekuasaannya memaksa seseorang memberikan sesuatu, membayar, atau menerima pembayaran dengan potongan, atau untuk mengadakan sesuatu bagi dirinya sendiri.

f. Pegawai negeri atau penyelenggara negara, pada waktu menjalankan tugas, meminta atau menerima, atau memotong pembayaran kepada pegawai negeri atau penyelenggara negara yang lain atau kepada kas umum, seolah-olah pegawai negeri atau penyelenggara negara yang lain atau kas umum tersebut mempunyai utang kepadanya, padahal diketahui bahwa hal tersebut bukan merupakan utang.

g. Pegawai negeri atau penyelenggara negara yang pada waktu menjalankan tugas, meminta atau menerima pekerjaan, atau penyerahan barang, seolah-olah merupakan utang kepada dirinya, padahal diketahui bahwa hak tersebut bukan merupakan utang.

h. Pegawai negeri atau penyelenggara negara yang pada waktu menjalankan tugas, telah menggunakan tanah negara yang di atasnya terdapat hak pakai, seolah-olah merupakan sesuai dengan peraturan perundang-undangan telah merugikan orang yang berhak, padahal diketahuinya bahwa perbuatan tersebut bertentangan dengan peraturan perundang-undangan; atau

i. Pegawai negeri atau penyelenggara negara baik langsung maupun tidak langsung dengan sengaja turut serta dalam pemborongan, pengadaan atau penyewaan, yang pada saat dilakukan perbuatan, untuk seluruh atau sebagian ditugaskan untuk mengurus atau mengawasi.

\section{B.ANALISIS KASUS}

\section{Landasan Hukum Pemidanaan terdakwa (dalam hal ini sudah terpidana) tidak tepat.}

\section{Ketentuan Pasal 12 a UU PTPK ditujukan kepada Pegawai Negeri dan atau Penyelenggara Negara.}

Pasal 12 UUPTPK menentukan:

Dipidana dengan pidana penjara seumur hidup atau paling singkat 4 (empat) tahun dan paling lama 20 (dua puluh) tahun dan pidana denda paling sedikit Rp. 200.000.000,- (dua ratus juta rupiah) dan paling banyak Rp. 1.000.000.000,- (satu milyar rupiah). 
a. Pegawai Negeri atau penyelenggara negara yang menerima hadiah atau janji, padahal diketahuinya atau patut diduga hahwa hadiah atau janji tersebut diberikan untuk menggerakkan agar melakukan atau tidak melakukan sesuatu dalam jabatannya, yang berhubungan dengan kewajibannya.

Unsur-unsur ketentuan Pasal 12 a UU PTPK adalah:

a. Pidana;

1) Penjara (paling singkat 4 (empat) tahun, paling lama 20 (dua puluh) tahun).

2) Denda (paling sedikit Rp.200.000.000,- (dua ratus juta rupiah), paling banyak Rp. 1.000.000.000,- (satu milyar rupiah).

b. Pegawai Negeri dan atau Penyelenggara Negara;

c. Hadiah atau janji;

d. Menggerakan agar melakukan atau tidak melakukan sesuatu dalam jabatannya.

Berkaitan dengan uraian di atas, dapat diketahui bahwa Pasal 12 a UU PTPK hanya berlaku untuk Pegawai Negara dan Penyelenggara Negara. Terpidana Sujendi Tarsono alias Ayen bukan merupakan Pegawai Negeri atau Penyelenggara Negara. Yang bersangkutan adalah sebagai wiraswasta sebagai Direktur PT Ada Mobil/Pemilik Ada Jadi Mobil.

Pasal 12 a UU PTPK pada dasarnya mengatur tentang perbuatan pegawai negeri atau penyelenggara negara yang bertentangan dengan tugas atau kewajibannya. Adapun tugas dan kewajiban masing-masing pegawai negeri atau panyelenggara negara tersebut bermacam-macam dan perbuatan yang bertentangan dengan tugas dan kewajiban itu beragam pula, misalnya ada yang bermaksud memperkaya diri sendiri, orang lain atau korporasi. Bagi pegawai negeri atau penyelenggara negara yang melakukan perbuatan yang bertentangan dengan tugas dan kewajibannya diancam dengan pidana sebagaimana dimaksud di dalam pasal ini.

Berkaitan dengan uraian di atas, kemungkinan yang terjadi adalah terjadinya error in persona. Istilah Error in Persona maupun Error in Objecto digunakan di pengadilan pada tahap eksepsi atas gugatan (kalau di perdata) atau dakwaan (kalau di pidana). Eksepsi dengan dasar Error in Persona di ajukan oleh Tergugat/Terdakwa terhadap Gugatan/Surat Dakwaan Penggugat/Penuntut Umum karena dakwaan/gugatan tersebut dialamatkan kepada orang yang salah. Mengenai istilah Error in Objecto pada prinsipnya adalah kesalahan gugatan/ dakwaan atas objek yang dipermasalahkan (dipersengketakan) 
atau peristiwa/ perbuatan yang didakwakan. Maka kesalahan atas objek yang dipersengketakan/ didakwakan tersebut disebut dengan Error in Objecto.

Bila terdakwa diposisikan sebagai yang Turut Serta Melakukan (Mededader), bahwa dalam Turut Serta Melakukan suatu tindak pidana berarti bahwa beberapa orang melakukan suatu tindak pidana secara bersama-sama. Syarat yang harus dipenuhi agar beberapa orang dapat disebut turut serta melakukan suatu tindak pidana adalah:

a. Melakukan secara bersama-sama dengan badan/fisiknya masingmasing.

b. Adanya kerjasama yang diinsyafi bersama-sama

Pada umumnya, kerjasama diinsyafi itu ada apabila para pembuat/pelaku terlebih dahulu mengadakan permufakatan sebelum tindak pidana dilakukan. Akan tetapi kerjasama yang diinsyafi dapat juga terjadi tanpa permufakatan, misanlnya si A sedang mencuri di duatu tempat (rumah), kemudaian si B lewat dan mengetahui bahwa si A itu sedang mencuri di sana, dan kemudian si B menjadi ikut mencuri di rumah yang sama. Di sini keturutsertaan si B dalam pencurian tidak didahului oleh permufakatan. Jadi mereka yang turut serta melakukan tindal pidana adalah mereka yang secara bersama-sama melakukan tindak pidana atau mereka yang dengan sengaja ikut melakukan. Yang penting dalam turut serta melakukan ini adalah bahwa 'ada kerjasama yang erat antara mereka' dan ini merupakan hakekat dari turut serta melakukan. Untuk menentukan apakah ada turut serta melakukan atau tidak, tidak dilihat kepada perbuatan masing-masing peserta secara satu persatu dan berdiri sendiri terlepas dari hubungan perbuatan-perbuatan peserta lainnya. Yang perlu diperhatikan ialah perbuatan masing-masing peserta dalam hubungan dan sebagai kesatuan dengan perbuatan peserta-peserta lainnya.

Menurut van Hattum, opzet (kesengajaan) seorang mededader (turut serta melakukan harus ditujukan kepada:

a. Maksud untuk kerjasama dengan orang lain untuk melakukan suatu tindak pidana.

b. Dipenuhinya semua unsur dari tindak pidana itu yang diliputi oleh opzet, yang harus dipenuhi oleh si pelakunya sendiri, yang sesuai dengan yang disyaratkan oleh rumusan tindak pidana yang bersangkutan.

Bagimana jika suatu tindak pidana yang hanya dapat dilakukan oleh seseorang yang mempunyai kedudukan (status) sebagai "pegawai negeri”, apakah tindak pidana itu dapat dilakukan bersama-sama (turut serta melakukan) dengan 
orang yang bukan pegawai negeri ? dalam hal ini, ada beberapa pendapat sebagai berikut :

a. Simons, berpendapat bahwa peserta dalah hal turut serta melakukan haruslah memiliki (memenuhi) syart-syarat sebagai pelaku (dader). Pendapatnya didasarkan kepada pasal 55 (1) KUHP : “... mereka yang melakukan, yang menyuruh melakukan dan turt serta melakukan”, ditulis dalam satu kalimat, yang hendaknya harus dibaca dalam satu nafas. Artinya, bahwa semua itu harus mempunyai syarat-syarat sebagai dader/pembuat. Jadi, para peserta mempunyai syarat-syarat sebagai pembuat. Dalam kaitannya dengan pertanyaan di atas, orang yang bukan pegawai negari tidak dapat sebagai orang yang turut serta melakukan.

b. Noyon, mengaitkan pasal 55 (1) KUHP dengan pasal 284 KUHP (perzinahan), yaitu bahwa sebagai pelaku adalah orang yang sedang terikat dalam perkawinan. Alasannya, bahwa yang dapat melakukan perzinahan adalah orang yang terikat dalam perkawinan yang sah, sedangkan orang yang tidak terikat dalam perkawinan yang sah tersebut, sebagai orang yang turut serta melakukan perbuatan pelaksanaan, tidak hanya sekedar 'mempermudah/memperlacar' perzinahan itu.

c. Hoge Raad, mendarkan pendaptnya kepada pasal 55 (1) KUHP : "Dipidana sebagai pelaku tindak pidana....." artinya, pidananya saja yang dipersamakan dengan orang yang melakukan tindak pidana itu. Jadi, tidak harus semua peserta memenuhi syarat-syarat sebagai pembuat/pelaku. Dalam kaitannya dengan pertanyaan di atas, baik pegawai negeri maupun yang bukan pegawai negeri dapat dianggap sebagai yang melakukan tindak pidana. Dengan demikian, menurut HR, ada unsur yang mutlak harus ada pada turut serta melakukan, yaitu kesengajaan atau keinsyafan ikut melakukan dan ada unsur yang tidak mutlak harus ada, yaitu status sebagai pegawai negeri.

Menurut saya hal ini penting dicermati dengan baik untuk menjamin agar setiap orang dalam situasinya dipertimbangkan secara individual, karena hal ini erat kaitannya dengan hak-hak yuridis dan konstitusional setiap orang yang harus dipertimbangkan secara tepat dan dilindungi. Hal ini juga penting karena karakter dan niat serta perbuatan seseorang dalam terjadinya suatu tindak pidana secara relatif berbeda, yang dapat dilihat pada pemeriksaan di persidangan yang merupakan fakta-fakta persidangan. 
Hal perlu dengan cermat difahami, agar tujuan hukum itu dapat dicapai sebagaimana mestinya. Tujuan hukum adalah untuk mewujudkan ketertiban dan keteraturan, kedamaian, serta keadilan. Hukum bertujuan untuk mengayomi manusia, mencegah tindakan sewenang-wenang dan pelanggaran hak, juga upaya untuk menciptakan kondisi dan mendorong manusia untuk selalu memanusiakan diri terus menerus. Di samping mewujudkan ketertiban dan keadilan, tugas hukum adalah menciptakan, keteraturan dan kepastian hukum.

Kepastian hukum merupakan kehendak setiap orang, bagaimana hukum harus berlaku atau diterapkan dalam peristiwa konkrit. Kepastian hukum berarti bahwa setiap orang dapat menuntut agar hukum dapat dilaksanakan dan tuntutan itu pasti dipenuhi, dan bahwa setiap pelanggaran hukum akan ditindak dan dikenakan sanksi menurut hukum. ${ }^{1}$

Sebagaimana diketahui bahwa sistem konstitusi menciptakan tertib hukum, yang memberi jaminan terhadap persamaan di depan hukum, menjamin tegaknya hukum, serta menjamin tercapainya tujuan hukum. Tertib hukum (rechtsorde) dimaksudkan suatu kekuasaan negara yang didasarkan pada hukum yang dikehendaki oleh hukum, dan keadaan masyarakat yang sesuai dengan hukum yang berlaku. Tertib hukum tercipta jika: a) suatu produk peraturan perundang-undangan tidak saling bertentangan, baik secara vertikal maupun secara horizontal, b) perilaku pelaksana kekuasaan negara dan anggota masyarakat sesuai dengan aturan hukum yang berlaku.

Ketertiban umum adalah suatu keadaan penyelenggaraan kehidupan manusia sebagai kehidupan bersama. Keadaan tertib yang umum menyiaratkan suatu keteraturan yang diterima secara umum sebagai suatu kepantasan minimal, supaya kehidupan bersama tidak berubah menjadi anarki. Ketertiban umum sering dibahas dengan menggunakan istilah yang berbeda-beda seperti "keadaan damai," "kepastian hukum." Dia memerlukan sesuatu yang mampu mengakibatkan bahwa keadaan masyarakat secara umum adalah tertib dan bukan sebaliknya; tata tertib hukum sebenarnya merupakan kepentingan objektif semua pihak dalam masyarakat. Artinya bila dibiarkan, keadaan umum masyarakat itu bisa saja tidak tertib. Keadilan belum tercapai dengan adanya ketertiban, karena keadilan lebih dari sekedar ketertiban. Ketertiban umum sebenarnya juga merupakan manifestasi dari suatu keadaan damai yang dijamin oleh keamanan kolektif yaitu suatu tatanan

${ }^{1}$ Franz Magnis Suseno, 1994, Etika Politik, Gramedia Pustaka Utama, Jakarta, hlm. 79. 
manusia merasa aman secara kolektif. Kebebasan dan pertanggungjawaban pribadi berkenaan dengan hukum.

\title{
2. Terdakwa sebagai Membantu Melakukan
}

\author{
Dalam Dakwaan Penuntut Umum tertera hal-hal sebagai \\ berikut:
}

1. "Bahwa Terdakwa SUJENDI TARSONO alias AYEN bersama-sama dengan OK. ARYA JULKARNAIN selaku penyelenggara Negara yaitu selaku Bupati Batubara masa jabatan 2013-2018 yang di angkat berdasarkan keputusan Mentri Dalam Negeri Republik Indonesia Nomor 131.12-7246 Tahun 2013.

2. Sekira bulan Desember 2016 bertempat di showroom "Ada Jadi Mobil" Terdakwa mengikuti pertemuan yang di hadiri OK. ARYA ZULKARNAIN, HELMAN HERDADY, dan MARINGIN SITUMORANG. Dalam pertemuan itu, OK. ARYA ZULKARNAIN meminta MARINGIN SITUMORANG untuk mengkordinir calon rekanan dengan mengatakan "kamu aja yang mengurus ... kamu panggil ... kamu kumpulkan ... dan upayakan yang pernah kerja di sana ..."

3. Bahwa selain menerima uang untuk OK. ARYA ZULKARNAIN, Terdakwa pada sekitar bulan Nopember 2016 juga menerima uang sejumlah Rp. 300.000.000,00 (tiga ratus juta rupiah) dari MARINGAN SITUMORANG untuk pribadi Terdakwa.

4. Bahwa selain penerima uang proyek pada tahun 2017 tersebut, Terdakwa yang bertindak atas nama OK. ARYA ZULKARNAIN juga mengatur untuk proyek tahun $2016 . . .$.

5. Bahwa Terdakwa mengetahui atau setidak-tidaknya patut menduga bahwa penerimaan uang total sejumlah Rp. 8.355.000.000,00 (delapan milyar tiga ratus lima puluh lima juta rupiah) yang bersumber dari para calon penyedia barang/jasa pelaksanaan pekerjaan jalan dan jembatan Kabupaten Batubara untuk kepentingan OK. ARYA ZULKARNAIN bertentangan dengan kewajiban Ok. ARYA ZULKARNAIN dan HELMAN HERDANDY

Dari uraian tersebut, dapat diketahui bahwa terdakwa SUJENDI TARSONO alias AYEN bertindak bukan untuk kepentingannya, tetapi bertindak untuk kepentingan OK. ARYA ZULKARNAIN yang berkedudukan sebagai Penyelenggara Negara. Sedang SUJENDI TARSONO alias AYEN adalah Wiraswasta dan bukan Pegawai Negeri atau Penyelenggara Negara.

Legal Opini Atas Putusan Pengadilan Tindak Pidana Korupsi Pada Pengadilan Negeri Medan Nomor 13/Pid.Sus-TPK/2018/PN Medan, Tanggal 19 April 
Menurut hemat saya, terdakwa SUJENDI TARSONO alias AYEN dapat dikategorikan dalam Turut Serta dalam terjadinya tindak pidana atau peristiwa pidana, sebagai orang yang disuruh oleh OK. ARYA ZULKARNAIN sebagai Penyelenggara Negara (Menyuruh Melakukan). Menyuruh melakukan adalah seseorang yang berkehendak untuk melakukan sesuatu tindak pidana, akan tetapi tidak melakukannya sendiri, melainkan menyuruh orang lain untuk melakukannya. Ajaran yang menyangkut dengan 'menyuruh melakukan' ini disebut juga 'middlelijk daders' artinya perbuatan dengan perantaraan. Orang yang menyuruh itu menggunakan orang lain (yaitu orang yang disuruh) untuk mewujudkan niatnya.

Syarat utama (ciri khas) dari menyuruh melakukan adalah bahwa seorang yang disuruh itu haruslah orang yang tidak dapat dipertanggungjawabkan secara hukum (menurut Hukum Pidana). Mengapa orang yang disuruh melakukan itu tidak dapat dipidana, pada hal dia sendiri yang melakukan tindak pidana itu ? Alasannya adalah sebagai berikut :

a. Karena adanya pengecualian pidana.

b. Karena salah satu unsur tindak pidana itu tidak dipenuhi, misalnya unsur kesalahan (kesengajaan), yang berkaitan dengan niat (sebagai unsur subjektif) dalam terjadinya tindak pidana.

Orang yang disuruh melakukan disebut dengan 'middelijkedader (manus domina), sedangkan orang yang disuruh disebut 'onmiddelijke dader' (manus ministra). Menyuruh melakukan terjadi sebelum dilakukannya perbuatan oleh pelaku marteril. Dalam menyuruh melakukan, pembuat materiil tidak dapat dipidana, yang dipidana adalah orang yang menyuruh melakukan. Bagaimana cara untuk 'menyuruh' tidak dipersoalkan. Yang menyuruh melakukan yang bersalah (mensrea) sedangkan yang melakukan tidak mempunyai kesalahan. Pertanggungjawaban dari orang yang menyuruh melakukan dibatasi hanya sampai pada perbuatan yang dilakukan oleh pembuat materil (orang yang disuruh).

\section{Hilangnya Unsur Melawan Hukum Materil}

Dari keputusan PUTUSAN PENGADILAN TINDAK PIDANA KORUPSI PADA PENGADILAN NEGERI MEDAN KELAS I A NOMOR 13/Pid.Sus-TPK/2018/PN Mdn Tanggal 19 April 2018, dapat diketahui hal-hal yang meringankan: 
a. Terdakwa telah mengembalikan uang suap yang di terimanya yaitu sebesar Rp. 150.000.000,- (seratus lima puluh juta rupiah);

b. Terdakwa mengakui terus terang perbuatannya;

c. Terdakwa juga telah mengembalikan uang milik saksi OK Arya Zulkarnain yang berasal dari Penyedia Barang/jasa di Kabupaten Batubara sejumlah Rp. 373.752.500,- (tiga ratus tuju puluh tiga juta tuju ratus lima puluh dua ribu lima ratus rupiah).

Berarti dapat dipahami bahwa tidak ada lagi kerugian negara, yang mana hal ini menghilangkan sifat melawan hukum materil. Berkaitan dengan hal ini, dapat dipedomani Putusan Mahkamah Agung RI Nomor: $42 \mathrm{~K} / \mathrm{Kr} / 1966$ tanggal 8 Januari 1966 yang kemudian diikuti pula Putusan Mahkamah Agung Nomor: 71/K/1970 tanggal 27 Mei 1972, Putusan Mahkamah Agung Nomor: 81/K/Kr/1973 tanggal 30 Mei 1977, Mahkamah Agung berpendapat bahwa adanya 3 (tiga) sifat hilangnya unsur (bestandellen) melawan hukum materil sebagai alasan penghapus pidana (yang tidak tertulis) berupa: faktor negara tidak dirugikan, kepentingan umum dilayani dan terdakwa tidak mendapat untung. Mahkamah Agung juga berpendirian dengan membenarkan pendapat dari Pengadilan Tinggi bahwa hilanganya sifat melawan hukum dapat juga dikarenakan asas-asas keadilan atau asas-asas hukum yang tidak tertulis, dimana Mahkamah Agung pada asasnya dapat membenarkan bahwa suatu tindakan pada umumnya dapat hilang sifatnya sebagai melawan hukum, bukan hanya berdasarkan suatu ketentuan dalam perundangundangan, melainkan juga berdasarkan asas-asas keadilan atau asas-asas hukum yang tidak tertulis dan bersifat umum. Yurisprudensi Mahkamah Agung yang berpendirian perbuatan melawan hukum materil dalam fungsi positif terdapat dalam perkara Putusan Nomor: 275 K/Pid/1983 Tanggal 29 Desember 1983 yang kemudian diikuti pula dalam Putusan Mahkamah Agung Nomor: $2477 \mathrm{~K} / \mathrm{Pid} / 1988$ Tanggal 23 Juli 1993, Putusan Mahkamah Agung Nomor: 1571 K/Pid/1993 Tanggal 18 Januari 1995). Pada asasnya, yurisprudensi Mahkamah Agung ini pertimbangan putusannnya bersifat futuristis dengan titik tolak penafsiran yang keliru pengertian "melawan hukum" dari yudex factie diidentifikasikan sebagai "melawan peraturan yang ada sanksi pidananya, dimana menurut Mahkamah Agung penafsiran terhadap sebutan "melawan hukum" tidak tepat, jika hal itu hanya dihubungakan dengan policy perkreditan direksi yang menurut Pengadilan Negeri tidak melanggar peraturan hukum yang ada sanksi pidananya, akan tetapi sesuai pendapat yang sudah berkembang dalam ilmu hukum, seharusnya hal itu diukur berdasarkan asas-asas hukum tak tertulis, maupun asas-asas yang bersifat umum menurut kepatutan dalam masyarakat.

Kemudian yurisprudensi Mahkamah Agung tersebut secara implisit memberikan pertimbangan bahwa penanganan kasus ini mengacu kepada pengertian melawan hukum materil dari fungsi positif, dimana menurut kepatutan Legal Opini Atas Putusan Pengadilan Tindak Pidana Korupsi Pada Pengadilan Negeri Medan Nomor 13/Pid.Sus-TPK/2018/PN Medan, Tanggal 19 April 
dalam masyarakat khususnya dalam perkara-perkara tindak pidana korupsi, apabila seorang pegawai negeri menerima fasilitas yang berlebihan serta keuntungan lainnya dari seorang lain dengan maksud agar pegawai negeri itu menggunakan kekuasaannya atau wewenangnya yang melekat pada jabatannya secara menyimpang, hal itu sudah merupakan "perbuatan melawan hukum", karena menurut kepatutan perbuatan itu merupakan perbuatan yang tercela atau perbuatan yang menusuk perasaan hati masyarakat banyak. Pada hakikatnya, petimbangan putusan Mahkamah Agung inilah yang dianggap sebagai perkembangan interpretasi futuristis yang menyelami perasaan keadilan masyarakat di satu pihak, di sisi lain berpendapat bahwa sejak putusan itu ajaran sifat melawan hukum materil telah mempunyai fungsi positif. Fungsi positif ini, menurut ajaran umum hukum pidana, tidak diperbolehkan karena bertentangan asas legalitas.

Hakim dalam memeriksa dan memutuskan perkara menghadapi suatu kenyataan bahwa hukum tertulis tersebut ternyata tidak selalu dapat menyelesaikan masalah yang dihadapi. Bahkan seringkali hakim harus menemukan sendiri hukum itu (Rechtsvinding), dan/atau menciptakan (rechtsschepping) untuk melengkapi hukum yang sudah ada, dalam memutus suatu perkara. Hakim atas inisiatif sendiri harus menemukan hukum, karena hakim tidak boleh menolak perkara dengan alasan hukum tidak ada, tidak lengkap, atau hukum samar-samar.Hakim harus senantiasa melengkapi diri dengan ilmu hukum, teori hukum, dan filsafat hukum. Hakim tidak boleh membaca hukum itu hanya secara normatif (yang terlihat) saja. Hakim dituntut untuk dapat melihat hukum itu secara lebih dalam, lebih luas, dan lebih jauh kedepan. Hakim harus dapat melihat hal- hal yang melatarbelakangi suatu ketentuan-ketentuan tertulis, pemikiran- pemikiran apa yang ada disana, dan bagaimana rasa keadilan dan kebenaran masyarakat akan hal itu. ${ }^{2}$ Dalam proses penciptaan hukum (recht cepping) tidak langsung serta merta terjadi begitu saja. Tahapan yang harus di lalui dapat melewati proses pengembanan hukum (recht bouvening), proses pembentukan hukum (recht vorming) dan proses penemuan hukum (recht vinding). Ini merupakan tahapan yang harus dilalui hakim dalam membuat penjatuhan vonis yang akan diberikan kepada para pelaku tindak pidana korupsi. Analogi dan sifat diskresi hakim dalam pemaknaan dan penafsiran hukum jika banyak digunakan dalam pemberian penjatuhan sanksi terhadap para pelaku justru akan membayakan sistem pengadilan di Indonesia. Hakim dan aparat penegak hukum ini belum teruji profesionalitas dan independensi dalam setiap penjatuhan vonis yang diberikan. Analogi dan penafsiran biasanya didasarkan pada adanya kekosongan hukum dan aturan tertulis masih multi tafsir baik dari segi norma hukum maupun asas yang

\footnotetext{
${ }^{2}$ Sugijanto Darmadi, Op.-Cit., hlm. 3.
} 
digunakan. Dengan adanya analogi dan penafsiran yang sewenang-wenang justru tidak akan mencapai terjadinya kepastian hukum. Sanksi tegas dan kepastian hukum merupakan jantung utama dalam penegakan hukum di Indonesia ketika dalam penjatuhan vonis yang akan diberikan oleh hakim. Menurut Penulis penggunaan analogi dan penafsiran harus ada pembatasan-pembatasan khusus yang mengarah pada kepastian hukum bukan terobosan hukum demi mencari keadilan semata-mata. Keadilan yang diagung-agungkan dalam praktek hanya digunakan sebagai celah dalam lobi-lobi dan perdangangan hukum saja. Pemaknaan terhadap "kerugian negara" harus dapat dijadikan parameter dalam pembuatan dasar putusan hakim. Pemaknaan tersebut mengingat aspek kejahatan yang ditimbulkan telah melibatkan kepentingan publik dan rakyat secara luas. Hakim harus tanggap dan cerdas dalam memahami norma dan azas hukum ini, karena sifatnya abstrak dan halus sulit untuk diditeksi. Dalam proses selanjutnya tidak boleh sampai terjadinya penyempitan hukum (recht vervijning). Puncak tertinggi wajib mencapai pada tahapan penyatuan hukum (recht verfusing). Pemaknaan penyatuan ini berawal dalam konteks filosofis dalam konstitusi, akan tetapi Penulis maknai tidak dalam arti sesempit itu. Penyatuan hukum merupakan bentuk penciptaan kepastian hukum yang dibungkus dengan rasa keadilan dan kemanfaatan. Setiap kata mengandung makna jika sudah dikaitkan dengan norma dan asas hukumnya. Penyatuan yang digunakan harus dapat mengelaborasikan semua unsur yang ada dan tidak boleh ada yang ditinggalkan.

Dalam praktek peradilan, hakim dalam menilai apakah seseorang yang oleh penuntut umum dalam tuntutannya dikategorikan sebagai justice collaborator berpegang pada Surat Edaran Mahkamah Agung Republik Indonesia (SEMA RI) Nomor 4 Tahun 2011 tentang Perlakuan bagi Pelapor Tindak Pidana (whistleblower) dan Saksi Pelaku yang bekerjasama(justice collaborators) di dalam perkara tindak pidana tertentu. SEMA No.4 Tahun 2011 memberikan pedoman untuk menentukan seseorang sebagai saksi pelaku yang bekerjasama (justice collaborator) adalah sebagai berikut:

a. Yang bersangkutan merupakan salah satu pelaku tindak pidana tertentu sebagaimana dimaksud dalam SEMA ini, mengakui kejahatan yang dilakukannya, bukan pelaku utama dalam kejahatan tersebut serta memberikan keterangan sebagai saksi di dalam proses peradilan.

b. Jaksa penuntut umum dalam tuntutannya menyatakan bahwa yang bersangkutan telah memberikan keterangan dan bukti-bukti yang sangat signifikan sehingga penyidik dan/atau penuntut umum dapat mengungkap tindak pidana dimaksud secara efektif, mengungkap pelaku lainnya yang memiliki peran lebih besar dan/atau mengembalikan asset-aset hasil suatu tindak pidana. 
Hal tersebut dikarenakan SEMA merupakan petunjuk bagi para hakim dalam pelaksanaan tugas jika suatu ketentuan belum diatur dalam peraturan perundangan yang ada, sehingga Mahkamah Agung memandang perlu untuk mencarikan landasan pemecahannya, agar ada kesatuan pendapat dalam menghadapi masalah yang sama. Perhatian Mahkamah Agung terhadap pelapor tindak pidana dan saksi pelaku didasarkan pada upaya untuk menumbuhkan partisipasi publik guna mengungkap tindak pidana dengan cara memberikan perlindungan hukum serta perlakuan khusus kepada setiap orang yang mengetahui, dan/atau menemukan suatu hal yang dapat membantu aparat penegak hukum untuk mengungkap dan menangani tindak pidana dimaksud secara efektif. Atas dasar pertimbangan tersebut, maka mahkamah Agung meminta kepada para hakim agar dapat memberikan perlakuan khusus dengan antara lain memberikan keringanan pidana dan/ atau bentuk perlindungan lainnya terhadap orang-orang yang dapat dikategorikan sebagai pelapor tindak pidana dan saksi pelaku yang bekerjasama.

Sebagaimana beberapa peraturan di atas, dapat dikatakan penunjukan yang memberikan status sebagai saksi pelaku yang bekerjasama (justice collaborator), adalah penyidik dalam melakukan penyidikan dan penuntut umum dalam tuntutannya, sehingga hal lain yang menjadi masalah dalam praktek peradilan adalah apakah hakim begitu saja dapat mengabulkan status justice collaborator yang telah ditetapkan oleh penyidik dan penuntut umum dalam tuntutannya.

Dalam menentukan justice collaborator, nampak adanya beda pandangan atau indikator yang dijadikan tolok ukur untuk menetapkan siapa yang dapat dinyatakan sebagai justice collaborator antara penyidik dan penuntut umum serta hakim yang memeriksa perkara. Penyidik dan penuntut umum cenderung berpegang pada saksi pelaku yang dapat memberikan keterangan dan bukti-bukti yang sangat signifikan sehingga penyidik dan/atau penuntut umum dapat mengungkap tindak pidana dimaksud secara efektif, dan mengungkap pelaku lainnya yang memiliki peran lebih besar dan/atau mengembalikan asset-aset hasil suatu tindak pidana. Sedangkan Hakim berpegang pada ketentuan bahwa justice collaborator adalah bukan pelaku utama. Kedua indikator tersebut adalah merupakan indikator yang telah digariskan dalam SEMA No.4 Tahun 2011, sehingga dalam menyikapi perbedaan indikator yang dijadikan alas an penetapan justice collaborator tersebut, seharusnya hakim secara bijaksana memberikan pertimbangan dalam menilai apakah pelaku utama dapat dijadikan sebagai justice collaborator atau tidak, sehingga putusan yang dijatuhkan akan lebih terasa memberikan keadilan kepada pelaku lain yang bukan pelaku utama.

Dengan adanya perbedaan penilaian tersebut, maka KPK menilai akan menjadi dampak buruk, karena aka nada keengganan bagi pelaku untuk Legal Opini Atas Putusan Pengadilan Tindak Pidana Korupsi Pada Pengadilan Negeri Medan Nomor 13/Pid.Sus-TPK/2018/PN Medan, Tanggal 19 April 
bekerjasama membongkar jaringan kasus korupsi yang terjadi, karena menganggap tidak ada penghargaan terhadap status justice collaborator yang diberikan oleh penyidik maupun penuntut umum. Hal tersebut karena KPKberanggapan dalam menetapkan seseorang pelaku sebagai pelaku yang bekerjasama (justicecollaborator) KPK telah berupaya selektif dengan mengacu pada : pelaku telah bekerjasama dalam mengungkap kasus yang melibatkan dirinya, dengan memberikan bukti-bukti yang signifikan, dan telah mengembalikan uang hasil korupsi, sehingga KPK dapat menjerat pelaku lain yang ikut dalam tindak pidana korupsi tersebut.

Berdasarkan data KPK pada tahun 2016 ada 21 (dua puluh satu) permohonan tersangka korupsi yang meminta status justice collaborator, yang dikabulkan ada 2 (dua), 10 (sepuluh) permohonan ditolak, dan 9 (sembilan) permohonan masih diproses. Dengan melihat pada fakta tersebut dapat dikatakan KPK cukup selektif dalam mengabulkan apakah seseorang dapat ditetapkan sebagai saksi pelaku yang bekerja sama atau tidak, dengan menggunakan kriteria yang dapat dipertanggungjawabkan sesuai dengan tujuan dari diterapkannya pelaku yang bekerjasama tersebut.

Sebagaimana telah dibahas sebelumnya Surat Edaran Mahkamah agung (SEMA) Nomor 4 Tahun 2011 telah memberikan batasan sebagai syarat pelaku yang bekerjasama membongkar tindak pidana, tidak dapat diberikan kepada "pelaku utama tindak pidana". Pelaku utama dalam tindak pidana dapat diartikan sebagai actorintelektual dari terjadinya suatu tindak pidana, sehingga dapat dibuat suatu indik:ator apakah seorang pelaku dapat dijadikan saksi pelaku yang bekerjasama atau tidak, dengan cara menilai seberapa penting atau bagaimana peran dari pelaku dalam suatu tindak pidana. Sebagai contoh: penghubung dalam suatu tindak pidana suap, bukan berarti dia bukan pelaku utama, karena boleh jadi inisiatif untuk meminta suap atau memberikan suap dating dari perantara tersebut, demikianpun penerima suap yang notabene Pejabat Pembuat Komitmen (PPK) misalnya, belum dapat dikatakan sebagai pelaku utama karena menerima suap, karena bisa jadi justru pihak rekanan yang berinisiatif untuk menyuap, dengan demikian penilaian sebagai saksi pelaku yang bekerjasama (justice collaborator) harus dilakukan secara selektif dan bijaksana, hal tersebut jangan sampaipelaku utama mendapat hukuman yang lebih ringan daripada pelaku yang hanya menerima bagian dari tindakan koruptif tersebut. Hal tersebut juga jangan sampai "maling teriak maling" dengan harapan akan mendapatkan keringanan hukuman karena telah menjadi pelaku yang bekerjasama dalam mengungkap tindak pidana. Dalam hal ini hakim tidak terikat pada penetapan penyidik maupun penuntut umum dalam tuntutannya mengenai justice collaborator, karena hakim berpegang pada pertimbangan akan memberikan hukuman yang sesuai dengan rasa keadilan masyarakat bukan pada Legal Opini Atas Putusan Pengadilan Tindak Pidana Korupsi Pada Pengadilan Negeri Medan Nomor 13/Pid.Sus-TPK/2018/PN Medan, Tanggal 19 April 
rasa keadilan pelaku yang bekerjasama.

Dalam Pasal 10 ayat (1) Undang-Undang No.13 Tahun 2006 jo UndangUndang No.31 Tahun 2014 tentang Perlindungan Saksi dan Korban disebutkan bahwa Saksi, Korban, Saksi Pelaku, dan/atau Pelapor tidak dapat dituntut secara hukum, baik pidana maupun perdata atas kesaksian dan/ataulaporan yang akan, sedang,atau telah diberikannya,kecuali kesaksian atau laporan tersebut diberikan tidak dengan iktikad baik. (2) Dalam hal terdapat tuntutan hukum terhadap Saksi, Korban, Saksi Pelaku, dan/atau Pelapor atas kesaksian dan/atau laporan yang akan, sedang, atau telah diberikan, tuntutan hukum tersebut wajib ditunda hinggakasus yang ia laporkan atau ia berikan kesaksian telah diputusoleh pengadilan danmemperolehkekuatan hukum tetap. Hal ini lah yang menurut Penulis dapat dijadikan dalam pertimbangan hakim dalam memberikan vonis yang akan dijatuhkan kepada seorang justice collaborator.

Perlu ditegaskan bahwa Penegak hukum menegakkan hukum sebagaimana mestinya dan tidak salah dalam menerapkan hukum, yang dalam hal ini menempatkan aturan hukum yang tidak berlaku lagi sebagai landasan pertimbangan hukum. Ketentuan Hukum yang tidak berlaku tidak dapat dipergunakan sebagai landasan oleh penegak hukum dalam hal ini Jaksa/Penuntut Umum sebagai landasan hukum dalam melakukan penuntutan atau pihak-pihak tertentu untuk memenuhi kepentingannya (dan menurut hemat saya tindakan ini dikategorikan sebagai tindakan penyelundupan hukum). Dalam tindakan penyelundupan hukum, hukum digunakan untuk memenuhi kepentingan pribadi atau golongan (vested interesting). Perilaku Penegakan Hukum, Mulai dari Penyidikan, Penuntutan, Persidangan, seyogianya bersifat mendidik, bukan melakukan penyelundupan hukum.

Perlu ditegaskan bahwa berkaitan dengan penegakan hukum, tatanan hukum yang berlaku dalam suatu masyarakat, pada dasarnya merupakan pengejawantahan cita hukum yang dianut dalam masyarakat yang bersangkutan ke dalam perangkat berbagai aturan hukum positif, lembaga hukum dan proses (perilaku birokrasi pemerintahan, penegak hukum dan warga masyarakat) berarti hukum yang berlaku dalam masyarakat tidak boleh bertentangan dengan nilai-nilai yang hidup dalam masyarakat.

\section{B. KESIMPULAN}

Dalam hubungan kemasyarakatan, setiap manusia mempunyai hak, dan bersamaan dengan itu timbul hukum. Hak Asasi Manusia (HAM) merupakan hakhak yang melekat pada manusia yang mencerminkan martabatnya, yang harus memperoleh jaminan hukum, sebab hak-hak hanya dapat efektif apabila hak-hak itu dapat dilindungi hukum. Hukum pada dasarnya merupakan pencerminan dari 
HAM, sehingga hukum itu mengandung keadilan atau tidak, ditentukan oleh HAM yang dikandung dan diatur atau dijamin oleh hukum itu. Hukum tidak dilihat sebagai refleksi kekuasaan semata-mata, tetapi juga harus memancarkan perlindungan terhadap hak-hak warga negara. Di samping itu Peranan Hukum dalam masyarakat adalah agar Pertama: Masyarakat dan individu bebas dari penindasan, baik penindasan dari luar atau bangsa lain maupun penindasan dari dalam oleh penguasa dan juga penindasan antara sesama anggota masyarakat. Kedua: masyarakat tidak diperlakukan secara otoriter, hukum tidak boleh menjadi alat kekuasaan penguasa, tidak boleh menjelma atau mempersonifikasi diri sebagai Hukum, kebebasan dan kemerdekaan individu tidak boleh ditentukan oleh kehendak atau keinginan penguasa. Ketiga: Keberadaan dan kedudukan penguasa berdasarkan aturan hukum yang berlaku, hukum menjadi pancang dan fundamen kekuasaan dan kewenangan penguasa, penguasa tidak boleh melampaui batas kewenangan dan fungsi yang diberikan hukum kepadanya, tindakan yang seperti itu bertentangan dengan hukum. Keempat: Karakteristik peran hukum yang paling esensial adalah menjamin keamanan dan melindungi hak dan kepentingan anggota masyarakat setempat dalam mengembangkan kehidupan pribadi, dan dalam mengejar kebahagiaan dan kesejahteraan spritual dan material, sebaiknya setiap individu harus taat dan tidak dibenarkan bertindak menurut sesuka hati. Hukum adalah untuk manusia, maka pelaksanaan Hukum atau penegakan Hukum harus memberikan manfaat dan kegunaan bagi masyarakat. Masyarakat sangat berkepentingan bahwa dalam pelaksanaan atau penegakan hukum dan keadilan.

Demikian analisis ini dibuat, dengan harapah semua pihak dapat memahami agar tidak timbul tindakan-tindakan yang tidak benar, apalagi kalau tindakantindakan itu mengarah kepada perbuatan kriminal. Saya mengharapkan, analisis singkat ini dapat bermanfaat bagi kita semua. Atas perhatiannya diucapkan banyak terima kasih.

\section{DAFTAR PUSTAKA}

Hiariej, Eddy O.S., 2014, Prinsip-prinsip Hukum Pidana, Cahaya Atma Pusaka, Yogyakarta

Hujibers, Theo, 1988, Filsafat Hukum Dalam Lintas Sejarah,Kanisius, Cetakan Kelima, Yogyakarta. -, 1994, Etika Politik, Gramedia Pustaka Utama, Jakarta

Ginsberg, Morris, 2003, Keadilan dalam Masyarakat, Cetakan Pertama, Pondok Edukasi, Bantul

Rahardjo, Satjipto, 2004, Hukum Progresif (Penjelajahan Suatu Gagasan). Majalah Hukum Hukum Newsletter Nomor 59 Desember 2004. Yayasan Pusat Pengkajian Hukum. Jakarta.

Legal Opini Atas Putusan Pengadilan Tindak Pidana Korupsi Pada Pengadilan Negeri Medan Nomor 13/Pid.Sus-TPK/2018/PN Medan, Tanggal 19 April 
Hukum Progresif sebagai Dasar Pembangunan Ilmu hukum Indonesia.Makalah yang disampaikan seminar nasional Menggagas Ilmu Hukum (Progresif) Indonesia, di Semarang, tanggal 8 Desember 2004.

. Tidak Hanya Memeriksa dan Mengadili. Harian Kompas, Jumat, 2 November 2007

-, 2007, Biarkan Hukum Mengalir (catatan kritis tentang pergulatan manusia dan hukum), Penerbit Buku Kompas, Jakarta.

------------, 2007. Membedah Hukum Progresif, Kompas, Jakarta.

Rifai, Ahmad, Penemuan Hukum Oleh Hakim Dalam Prespektif Hukum Progresif, 2010, Sinar Grafika, Jakarta.

Republik Indonesia, Undang-Undang Republik Indonesia No.35 Tahun 2009, Tentang Narkotika.

Tentang Kekuasaan Kehakiman.

Soerjono Soekanto, 1998, Metodologi Research, Andi Offset, Yogyakarta,

Warlan Yusuf, Asep, Memuliakan Hukum dalam Alam Demokrasi yang Berkeadilan, Makalah disajikan dalam memperingati 70 tahun Prof. Dr. B. Arief Sidharta, SH., Bandung 